\title{
Utilization of Peanut and Jaggery for the Development of Nutri-rich Peanut Energy Bar and Jaggery Balls
}

\author{
Apoorva Jaiswal*, Alka Gupta and Tripti Verma
}

\author{
Department of Food Nutrition and Public Health, Ethelind College of Home Science, \\ SHUATS, PRAYAGRAJ, India \\ *Corresponding author
}

\begin{tabular}{l} 
K e y w o r d s \\
$\begin{array}{l}\text { Peanut energy bar, } \\
\text { Jaggery ball, } \\
\text { Organoleptic, } \\
\text { Nutritional } \\
\text { composition, Cost } \\
\text { calculation }\end{array}$ \\
\hline Article Info \\
$\begin{array}{l}\text { Accepted: } \\
\text { 07 September } 2020 \\
\text { Available Online: } \\
10 \text { October } 2020\end{array}$ \\
\hline
\end{tabular}

\section{A B S T R A C T}

This research was designed to produce a nourishing peanut energy bar and jaggery balls with commercial value especially for malnourished children to meet their body development requirements. Among the Various possible approaches to tackle the problem of malnutrition, food based approach is considered the most sustainable one, despite being a long term strategy. Hence, exploring the possibility of value addition to traditional products like energy bars, laddo, mathari and biscuits could be a better option to enhance the intake of micronutrients. Nutrition bars are supplemental bars containing high energy foods. The thesis was undertaken with two main objectives. The first objective was to optimize the level of ingredients using ANOVA. The second objective was to found the nutritive value from the ingredients namely peanut, jaggery, pumpkin seed powder and amaranth seed. Organoleptic evaluation of "Peanut energy bar" and "Jaggery Ball" indicates that $\mathrm{T}_{2}$ (roasted peanut + jaggery+ pumpkin seed powder + amaranth seed) had the highest score showed that the overall acceptability was highest in $\mathrm{T}_{2}$ followed by $\mathrm{T}_{0}, \mathrm{~T}_{1}$ and $\mathrm{T}_{3}$ respectively and there was a significant difference, $(\mathrm{p}<0.05)$ between the control and treatment. The nutritional composition of the best product $\mathrm{T}_{3}$ increased with the incorporation of prepared mix powder in Peanut energy bar the Moisture and Ash content was found to be 10.87 percent and $5.6 \mathrm{~g} / 100$, Protein content is $61.65 \mathrm{~g}$, Fat-177.2g, Fibre$1.209 \mathrm{~g}$ and Carbohydrate-516.59 g, Iron-21.84, Calcium-36.27, Vitamin C- 1.73 and Energy 497.32 (kcal). The nutritional composition of the best product $\mathrm{T}_{2}$ increased with the incorporation of prepared mix powder in Jaggery ball the Moisture and Ash content was found 31.29 percent and $10.47 \mathrm{~g} / 100$, Protein content- $171.51 \mathrm{~g}$, Fibre-3.26g, Carbohydrate-38.99g, Iron- 21.84, Calcium- 36.27, Vitamin-1.73 and Energy385.25(kcal). The cost of the Peanut energy bar $\mathrm{T}_{0}(8 \mathrm{Rs}),. \mathrm{T}_{1}(11.5 \mathrm{Rs}),. \mathrm{T}_{2}(11.25 \mathrm{Rs}$.$) and$ $\mathrm{T}_{3}$ (11 Rs.) The cost of the Jaggery ball $\mathrm{T}_{0}$ (4.5Rs.), $\mathrm{T}_{1}$ (9.9 Rs.), $\mathrm{T}_{2}$ (9.55 Rs.) and $\mathrm{T}_{3}(9.8$ Rs.). Peanut energy bar and Jaggery ball should be recommended for all age groups as it helps to boost immunity and also improves physical growth and good memory.

\section{Introduction}

Malnutrition is widely recognized as a major health problem in developing countries.
Growing children in particular are most vulnerable to its consequences. Cases with mild-to-moderate malnutrition are likely to remain unrecognized because clinical criteria 
for their diagnosis are imprecise and are difficult to interpret accurately. Studies have suggested that there is a need to focus on the youngest children in nutrition programs to prevent long-term effects (Victoria et al., 2008).

For the fulfillment of necessary nutrient and to tackle the malnutrition and micronutrient supplementation among the all age group those are suffering from micronutrient deficiency and malnutrition related poor outcomes thus the product which were formalized to fulfill the objectives of the study must contained the ingredient those were protein energy rich micronutrient foods like Peanuts which is significantly provide essential proteins that are often lacking in vegetarians, elderly, and people in acute stress due to illness and disease. Peanuts and peanut products also contain many of the vitamins, minerals, and nutrients that obese people need - often, these individuals are eating suboptimal diets. They also contain the good fats that research has found to aid in reducing cardiovascular risk and managing type 2 diabetes. Peanuts and peanut products are full of nutrients and energy for people requiring extra calories to heal during illness who can't eat a lot. Pumpkin seeds contain a wide variety of antioxidant phytonutrients, including the phenolic acids hydroxybenzoic, caffeic, coumaric, ferulic, sinapic, protocatechuic, vanillic and syringic acid; and the lignans pinoresinol, medioresinol and lariciresinol. Pumpkin seeds also contain health-supportive phytosterols, including beta-sitosterol, sitostanol and avenasterol. Pumpkin seeds are a very good source of phosphorus, magnesium, manganese and copper. They are also a good source of other minerals including zinc and iron. In addition, pumpkin seeds are a good source of protein. Jaggery is a natural, traditional sweetener made by the concentration of sugarcane juice. In Ayurvedic way of medicine it is used as medicine, blood purifier and also it prevents disorders of bile. Amaranth seed is gluten-free and may be used to prepare nutritious and suitable food products for people with this type of food allergy. Besides proteins, carbohydrates, and lipids, amaranth seeds contain various other constituents of making amaranth a super food because it also counts with elevated levels of vitamin E, vitamin B2 (riboflavin), and vitamin $\mathrm{C}$ (ascorbic acid). It is also important to mention that saponins are found in very low levels $(0.1 \%)$ in amaranth grain which makes it completely safe for human consumption.

\section{Materials and Methods}

The study entitled was Utilization of Peanut and Jaggery for the development of nutri-rich "Energy bar" and "Jaggery balls" conducted in the Nutrition Research Laboratory, Department of Food Nutrition and Public Health, Ethelind College of Home Science, Sam Higginbottom University of Agriculture Technology and Sciences, Prayagraj-211007, U.P. India.

The details of materials, equipment, procedure and techniques adopted during the course of present investigation have been elaborated in this chapter under the following headings:

\section{Experimental site}

The present investigation was carried out in the Department of Food, Nutrition and Public Health, Ethelind College of Home Science, SHUATS, Prayagraj.

\section{Procurement of raw material}

The raw materials for the development of food products like Peanut, Jaggery, Pumpkin seeds, and Amaranth seeds were purchased from the local markets of Prayagraj. 
Pre-preparation of develop value added products- pumpkin seed powder and amaranth seed

Pumpkin seeds and amaranth seeds were purchased from the local markets of Prayagraj. Process of roasting and grinding was done for the preparation of pumpkin seed powder.

\section{Development of the value added products}

Value added food product were prepared with incorporation of Jaggery, Pumpkin seed powder and Amaranth. For each product, the basic recipe (control $\mathrm{T}_{0}$ ) had three variations, $\mathrm{T}_{1}, \mathrm{~T}_{2}, \mathrm{~T}_{3}$ respectively, where the amount of one or more ingredients was varied.

Treatment and replications of the product

Preparation of peanut energy bar and jaggery ball

Peanut energy bar and jaggery ball prepared by using different ratios of nutritive value.

\section{Preparation method of peanut energy bar}

To formulized the peanut energy bar firstly, in a thick bottomed pan dry roasted peanut on a medium to low heat then took grated jaggery and poured 1 tbsp water it begins to dissolve on a low medium heat after that checked the syrup consistency and caramelized the jiggery after that stirred the peanuts, pumpkin seed powder and amaranth seed with jaggery syrup now transferred to the steel plate greased, spreaded with the help of a small cup to smoothen the top.

Allow it to cooled for a minute, and when it's still warmed cut into pieces. Lastly, served peanut bar once cooled completely and stored in air tight jar (shown in plate.1 and Table 1).

\section{Preparation method of jaggery ball}

Kept the flames to low or medium add the raw peanuts and roasted in a hot pan. Now cooled the peanuts completely then transfered the roasted peanuts into a mixer and blended to a coarse powder. Then In a large pan added jaggery and kept stirred on low flame, until the jaggery dissolved and added peanut powder, pumpkin seed powder, wheat flour and amaranth seed and mixed well after that made balls when the mixture was still warm, as it hardens once cooled. Finally stored jaggery balls in an airtight jar. (shown in plate 2) (Table 2).

\section{Sensory evaluation}

Sensory evaluation of the food products for their acceptability was done by a panel of 5 judges. The score card based on the 9 point Hedonic Scale was used for sensory evaluation on the basis of evaluation of attributes like Colour and Appearance, Body and Texture, Taste and Flavour, overall Acceptability (Srilakshami, 2007).

\section{Determination of cost}

Cost of the prepared products were calculated taking into account the cost of individual raw ingredients used in the preparation of the food products at the prevailing market price.

\section{Statistical analysis}

Analysis of variance technique (ANOVA), and Critical difference were used to analyze the data (Gupta and Karoo, 2002).

\section{Results and discussion}

Organoleptic evaluation of Peanut energy bar and Jaggery ball

Two products were prepared 'Peanut Energy Bar' and 'Jaggery Ball' by the incorporation 
of jaggery, peanut, amaranth, pumpkin seed powder, wheat flour. The basic recipe of Peanut energy bar with the incorporation of pumpkin seed powder as a control and basic recipe for Jaggery ball with the incorporation of wheat flour and pumpkin seed powder served as control. Peanut energy bar and Jaggery ball with the three treatments of each product i.e., $\mathrm{T}_{1}$ (Peanut+ jaggery+ pumpkin seed powder + amaranth seed in ratio of
30:50:10:10), $\mathrm{T}_{2}$ (Peanut + jiggery + pumpkin seed powder + amaranth seed in ratio of 25:50:10:10), $\mathrm{T}_{3}$ (Peanut + jiggery + pumpkin seed powder + amaranth seed in ratio 25:50:10:15) (shown in Graph 1 and Graph 2 respectively). The organoleptic evaluation of products with regard to attributes of colour, body and texture, flavor, taste and overall acceptability were done using a nine point hedonic scale (Table 3 and 4).

Table.1 Preparation of Peanut energy bar with incorporation of Jaggery

\begin{tabular}{|l|c|c|c|c|c|}
\hline Product/Ingredient & $\mathbf{T}_{\mathbf{0}}$ & $\mathbf{T}_{\mathbf{1}}$ & $\mathbf{T}_{\mathbf{2}}$ & $\mathbf{T}_{\mathbf{3}}$ & Replication \\
\hline Peanut & $50 \%$ & $30 \mathrm{~g}$ & $25 \mathrm{~g}$ & $20 \mathrm{~g}$ & 5 \\
\hline Jaggery & $50 \%$ & $50 \mathrm{~g}$ & $50 \mathrm{~g}$ & $50 \mathrm{~g}$ & 5 \\
\hline $\begin{array}{l}\text { Pumpkin seed } \\
\text { Powder }\end{array}$ & - & $10 \mathrm{~g}$ & $10 \mathrm{~g}$ & $10 \mathrm{~g}$ & 5 \\
\hline \begin{tabular}{l} 
Amaranth \\
\hline
\end{tabular} & - & $10 \mathrm{~g}$ & $15 \mathrm{~g}$ & $20 \mathrm{~g}$ & 5 \\
\hline
\end{tabular}

Table.2 Preparation of Jaggery Ball with incorporation of Wheat Flour

\begin{tabular}{|l|c|c|c|c|c|}
\hline Product/Ingredient & $\mathbf{T}_{\mathbf{0}}$ & $\mathbf{T}_{\mathbf{1}}$ & $\mathbf{T}_{\mathbf{2}}$ & $\mathbf{T}_{\mathbf{3}}$ & Replication \\
\hline Jaggery & $50 \%$ & $50 \mathrm{~g}$ & $50 \mathrm{~g}$ & $50 \mathrm{~g}$ & 3 \\
\hline Wheat Flour & $50 \%$ & $20 \mathrm{~g}$ & $30 \mathrm{~g}$ & $25 \mathrm{~g}$ & 3 \\
\hline Peanut Powder & - & $10 \mathrm{~g}$ & $5 \mathrm{~g}$ & $10 \mathrm{~g}$ & 3 \\
\hline Pumpkin seed Powder & - & $10 \mathrm{~g}$ & $10 \mathrm{~g}$ & $10 \mathrm{~g}$ & 3 \\
\hline Amaranth & - & $10 \mathrm{~g}$ & $5 \mathrm{~g}$ & $5 \mathrm{~g}$ & 3 \\
\hline
\end{tabular}

Table.3 The average nutritional composition of control and the best treatment samples of "Peanut Energy Bar" per 100g

\begin{tabular}{|l|c|c|c|c|c|c|}
\hline Nutrients & $\mathbf{( T 0 )}$ & $\mathbf{( T 3 )}$ & $\begin{array}{c}\text { Difference } \\
\text { (T1-T0=D) }\end{array}$ & T(calculated) & $\begin{array}{c}\text { T(tabulated } \\
\text { value at 5\%) }\end{array}$ & Result \\
\hline Moisture(\%) & 4.37 & 5.5 & 1.13 & 2.96 & 4.303 & NS \\
\hline Ash(g) & 4.60 & 5.6 & 0.75 & 7.91 & 4.303 & S \\
\hline Protein(g) & 14.68 & 15.3 & 24.7 & 61.65 & 4.303 & S \\
\hline Fat(g) & 21.69 & 22.2 & 35.17 & 177.2 & 4.303 & NS \\
\hline Crude fiber(g) & 1.84 & 2.06 & 0.682 & 1.209 & 4.303 & NS \\
\hline Carbohydrates(g) & 52.24 & 53.3 & 200.07 & 516.59. & 4.303 & NS \\
\hline Iron(mg) & 0.79 & 1.01 & 0.22 & 21.84 & 4.303 & S \\
\hline Calcium(mg) & 63.3 & 13.13 & 51 & 36.27 & 4.303 & S \\
\hline Vitamin C(mg) & 3.7 & 4.16 & 0.46 & 1.73 & 4.303 & NS \\
\hline Energy(kcal) & 471.5 & 472.5 & 958.636 & 4975.32 & 4.303 & NS \\
\hline
\end{tabular}


Table.4.3 (B) The Average nutritional composition of control and the best treatment samples of "Jaggery Ball" per $100 \mathrm{~g}$

\begin{tabular}{|l|c|c|c|c|c|c|}
\hline \multicolumn{1}{|c|}{ Nutrients } & $(\mathbf{T 0})$ & $\mathbf{( T 2 )}$ & $\begin{array}{c}\text { Difference } \\
(\mathbf{T 1}-\mathbf{T 0}=\mathbf{D})\end{array}$ & T(calculated) & $\begin{array}{c}\text { T(tabulated } \\
\text { value at 5\%) }\end{array}$ & Result \\
\hline Moisture(\%) & 10.47 & 11.2 & 10.013 & 23.38 & 4.303 & $\mathrm{~S}$ \\
\hline Ash(g) & 4.85 & 5.6 & 0.75 & 7.91 & 4.303 & $\mathrm{~S}$ \\
\hline Protein(g) & 20.73 & 21.5 & 67.096 & 171.51 & 4.303 & $\mathrm{~S}$ \\
\hline Fat(g) & 22.54 & 23.3 & 79.806 & 204.50 & 4.303 & $\mathrm{~S}$ \\
\hline Crude fiber(g) & 1.68 & 0.92 & 0.3592 & 0.60130 & 4.303 & NS \\
\hline Carbohydrates(g) & 86.94 & 87.4 & 16.026 & 38.99 & 4.303 & $\mathrm{~S}$ \\
\hline Iron(mg) & 0.79 & 1.01 & 0.22 & 21.84 & 4.303 & $\mathrm{NS}$ \\
\hline Calcium(mg) & 63.3 & 13.13 & 51 & 36.27 & 4.303 & $\mathrm{~S}$ \\
\hline Vitamin C(mg) & 3.7 & 4.16 & 0.46 & 1.73 & 4.303 & $\mathrm{NS}$ \\
\hline Energy(kcal) & 642 & 650.5 & 107151.7 & 38542.25 & 4.303 & $\mathrm{~S}$ \\
\hline
\end{tabular}

Table.4.4 Cost of the prepared product 'Peanut Energy Bar'

\begin{tabular}{|c|c|c|c|c|c|c|c|c|c|}
\hline \multirow[t]{3}{*}{ Ingredients(g) } & \multirow{3}{*}{$\begin{array}{c}\text { Actual } \\
\text { rate/K } \\
\mathbf{g}(\mathbf{R s})\end{array}$} & \multicolumn{8}{|c|}{ Treatments } \\
\hline & & \multicolumn{2}{|c|}{$\mathbf{T}_{0}$} & \multicolumn{2}{|c|}{$\mathbf{T}_{1}$} & \multicolumn{2}{|c|}{$\mathbf{T}_{2}$} & \multicolumn{2}{|c|}{$\mathbf{T}_{3}$} \\
\hline & & $\begin{array}{c}\text { Quantity } \\
\text { (g) }\end{array}$ & $\begin{array}{l}\text { Cost } \\
\text { (Rs) }\end{array}$ & $\begin{array}{c}\text { Quantity } \\
\text { (g) }\end{array}$ & $\begin{array}{l}\text { Cost } \\
\text { (Rs) }\end{array}$ & $\begin{array}{c}\text { Quantity } \\
\text { (g) }\end{array}$ & $\begin{array}{l}\text { Cost } \\
\text { (Rs) }\end{array}$ & $\begin{array}{c}\text { Quanti } \\
\text { ty(g) }\end{array}$ & $\begin{array}{l}\text { Cos } \\
(\mathbf{R s})\end{array}$ \\
\hline Peanut & 100 & 50 & 5 & 30 & 3 & 25 & 2.5 & 20 & 2 \\
\hline Jaggery & 60 & 50 & 3 & 50 & 3 & 50 & 3 & 50 & 3 \\
\hline $\begin{array}{l}\text { Pumpkin seed } \\
\text { Powder }\end{array}$ & 500 & - & - & 10 & 5 & 10 & 5 & 10 & 5 \\
\hline Amaranth seed & 50 & - & - & 10 & 0.50 & 15 & 0.75 & 20 & 1 \\
\hline Total amount in Rs. & & & 8 & & 11.5 & & 11.25 & & 11 \\
\hline
\end{tabular}

Table.4.4 Cost of the prepared product 'Jaggery Ball'

\begin{tabular}{|c|c|c|c|c|c|c|c|c|c|}
\hline \multirow[t]{3}{*}{ Ingredients(g) } & \multirow{3}{*}{$\begin{array}{c}\text { Actual } \\
\text { rate/Kg } \\
\text { (Rs) }\end{array}$} & \multicolumn{8}{|c|}{ Treatments } \\
\hline & & \multicolumn{2}{|c|}{$\mathbf{T}_{\mathbf{0}}$} & \multicolumn{2}{|c|}{$\mathbf{T}_{1}$} & \multicolumn{2}{|c|}{$\mathbf{T}_{2}$} & \multicolumn{2}{|c|}{$\mathbf{T}_{3}$} \\
\hline & & $\begin{array}{c}\text { Quantity } \\
\text { (g) }\end{array}$ & $\begin{array}{l}\text { Cost } \\
\text { (Rs) }\end{array}$ & $\begin{array}{l}\text { Quantity } \\
\text { (g) }\end{array}$ & $\begin{array}{l}\text { Cost } \\
\text { (Rs) }\end{array}$ & $\begin{array}{l}\text { Quantity } \\
\text { (g) }\end{array}$ & $\begin{array}{l}\text { Cost } \\
\text { (Rs) }\end{array}$ & $\begin{array}{c}\text { Quantity } \\
\text { (g) }\end{array}$ & $\begin{array}{l}\text { Cost } \\
(\mathbf{R s})\end{array}$ \\
\hline Jaggery & 60 & 50 & 3 & 50 & 3 & 50 & 3 & 50 & 3 \\
\hline Wheat flour & 30 & 50 & 1.5 & 20 & 0.60 & 30 & 0.90 & 25 & 0.75 \\
\hline Peanut powder & 80 & - & - & 10 & 0.80 & 5 & 0.40 & 10 & 0.80 \\
\hline $\begin{array}{l}\text { Pumpkin seed } \\
\text { powder }\end{array}$ & 500 & - & - & 10 & 5 & 10 & 5 & 10 & 5 \\
\hline Amaranth seed & 50 & - & - & 10 & 0.50 & 5 & 0.25 & 5 & 0.25 \\
\hline Total amount in Rs. & & & 4.5 & & 9.9 & & 9.55 & & 9.8 \\
\hline
\end{tabular}


Plate.1 Peanut energy bar prepared by incorporating pumpkin seed powder, peanut powder and amaranth seed powder

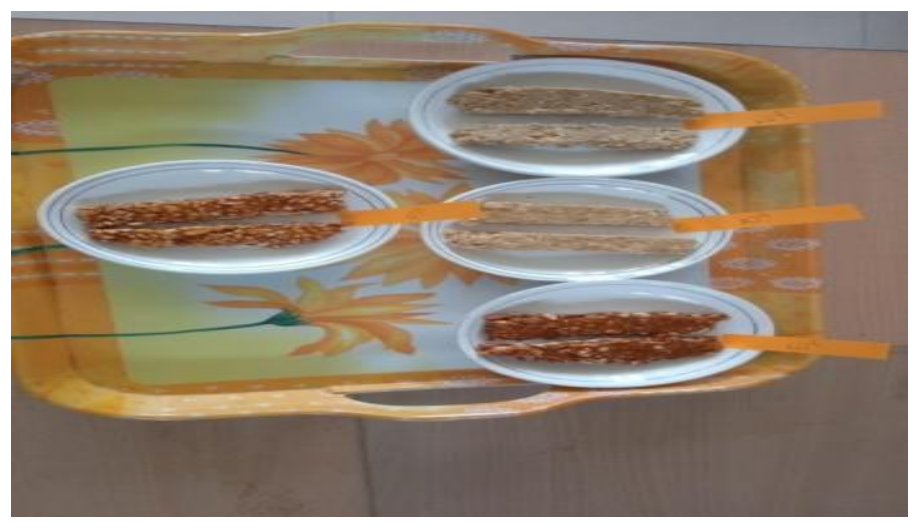

Plate.2 Jaggery Ball' prepared by incorporating pumpkin seed powder, peanut powder and amaranth seed

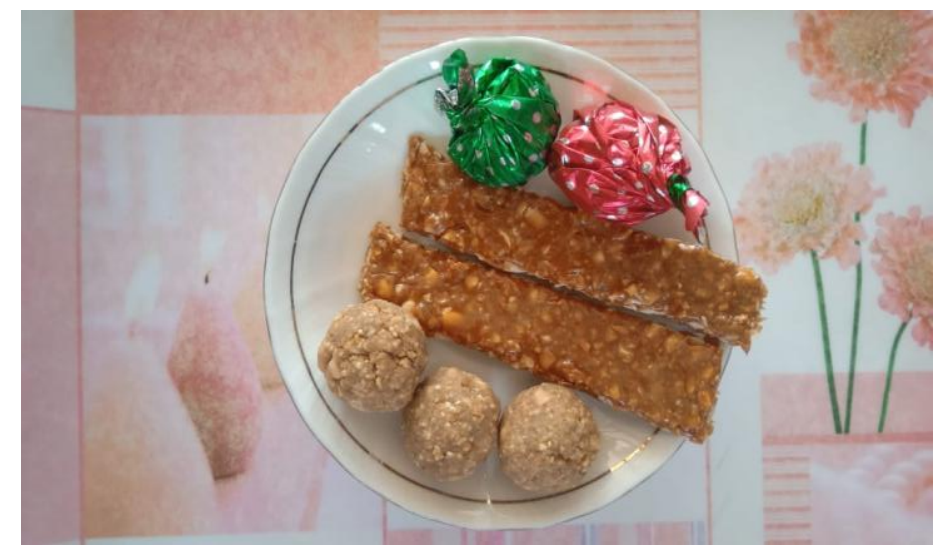

Graph.1 Organoleptic evaluation of peanut energy bar

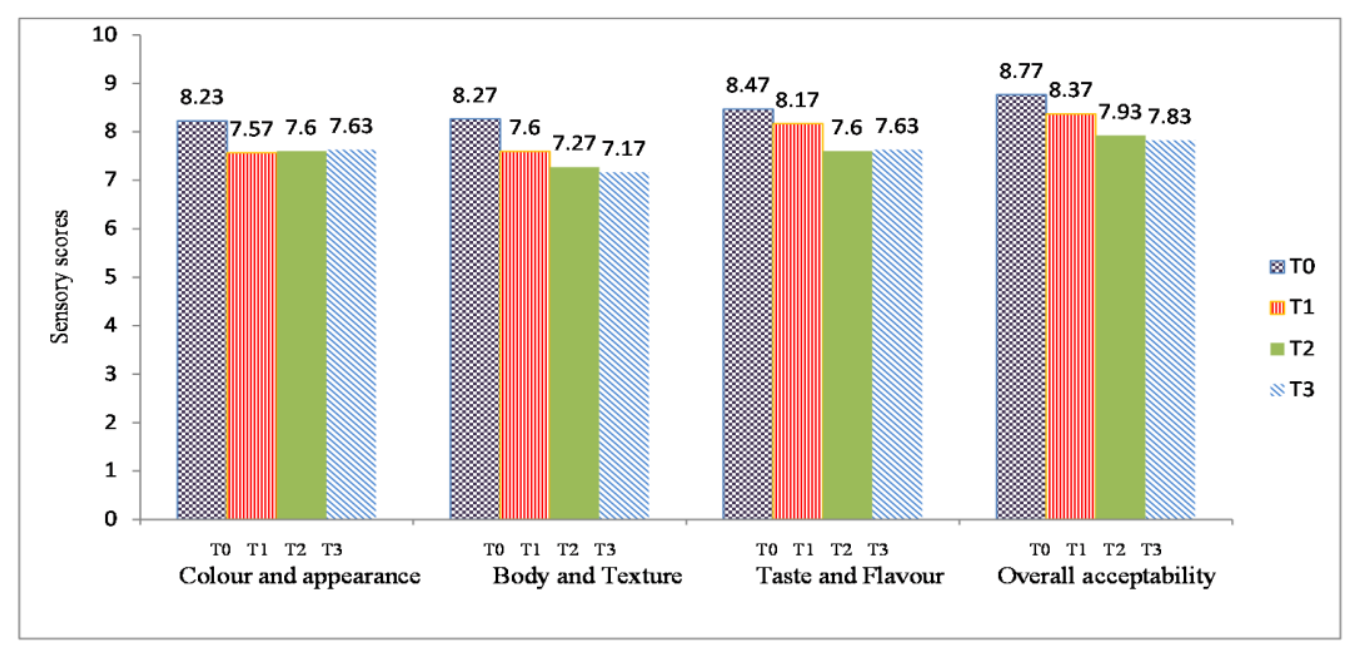


Graph.2 Organoleptic evaluation of Jaggery Ball

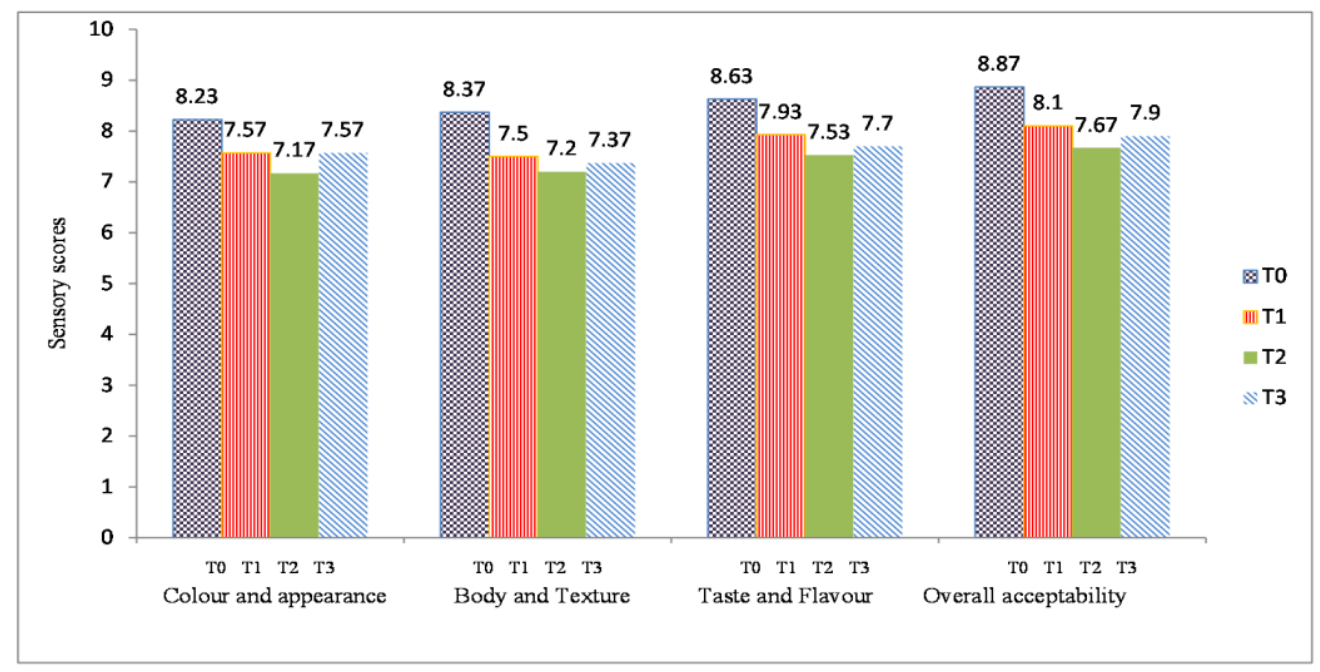

The finding of the entire study is reported as follows: The observations were recorded, tabulated and results were statistically analyzed by analysis of variance technique, critical difference and t-test. The result is supported by the finding of Silpa Somavarapu and B. Suryam (2019) find out the acceptability of iron-rich ladoos containing five different combinations of ragi flour, bajra flour, soy flour and jaggery in the ratio of 1:1:1.5:1.5 with raisins for garnishing was accepted the most. It produced highest acceptability and the data revealed an overall acceptability of ladoos.

\section{Nutritional Composition of the Developed Product "Peanut Energy Bar"}

This study was supported by Richa Singh et al., (2017) develop chikki using nutritious ingredients like flax seeds, pumpkin seeds, watermelon seeds, sesame seeds and jaggery. Four prepared samples were presented, Sample A, with 2.5 grams of incorporation was found to be the most acceptable product having an iron content of $6.2 \mathrm{mg} / 100 \mathrm{~g}$, which can fulfill around $30 \%$ of the daily iron requirement of a normal adult female.
Nutritional Composition of the Developed Product "Jaggery Ball"

Cost of the prepared product based on raw materials

In conclusion the energy bar are supplemental bars containing cereals and other high energy foods targeted at people who require quick energy but do not have time for a meal. They are different from energy drinks, which contain caffeine whereas bars provide food energy. Peanut are an excellent and affordable source of nutrition, supplementing vital nutrients to the human body such as proteins, carbohydrates, lipids, vitamins, minerals and fiber, Peanuts are often referred as poor man's protein but, when taken in adequate amounts in any form, will supplement rich nutrients to the body that can provide growth and energy, and play a vital role in the prevention of diseases. On the basis of findings, it is concluded that pumpkin seed powder was successfully incorporated in the preparation of the products like Peanut energy bar and Jaggery ball. Sensory evaluation showed that the treatment $\mathrm{T}_{3}$ (Peanut+ jaggery+ pumpkin seed powder+ amaranth seed) was the most acceptable in Peanut energy bar and in 
Jaggery ball showed that the treatment $T_{2}$ was found most highly acceptable. The incorporation levels of pumpkin seed powder increased the cost but it is comparatively cheaper than the control even through it was marginal. Peanut Energy Bar and Jaggery Ball can be recommended for the overall development of the malnourished children who are suffering from severe stunting and wasting growth defects in their physical and mental growth stage.

\section{References}

Glew RH, Glew RS, Chuang LT et al., (2006) Amino acid, mineral and fatty acid content of pumpkin seeds (Cucurbita spp) and Cyperus esculentus nuts in the Republic of Niger. Plant Foods Hum Nutr. 61(2): 51-6.

Gong Y.Y., Egal S., Hounsa A., Turner P.C., et al., (2003) Determinants of aflatoxin exposure in young children from Benin and Togo, West Africa: The critical role of weaning. Int. J. Epidemiol. 32: 556562.
Khlangwiset P., Shepherd G.S., Wu F et al., (2011) Aflatoxins and growth impairment: A review. Crit. Rev. Toxicol. 41: 740-755.

Manuel Soriano-Garcia and Isabel Saraid Aguirre-Diaz., (2019). Nutritional Functional Value and Therapeutic Utilization of Amaranth, Nutritional Value of Amaranth, Viduranga Y. Waisundara.

Sylla A., Gong Y.Y., Sutcliffe A.E. et al., (2005) Reduction in exposure to carcinogenic aflatoxins by postharvest intervention measures in West Africa: A community-based intervention study. Lancet. 365: 1950-1956.

Turner P.C., Collin son A.C., Cheung Y.B., et al., (2007) Aflatoxin exposure in utero causes growth faltering in Gambian infants. Int. J. Epidemiol. 36: 11191125.

Victoria C.G., Adair L., et al (2008) Maternal and child under nutrition, consequences for adult health and human capital. Lancet, 371. (9609). Pp. 340-357.

\section{How to cite this article:}

Apoorva Jaiswal, Alka Gupta and Tripti Verma. 2020. Utilization of Peanut and Jaggery for the Development of Nutri-rich Peanut Energy Bar and Jaggery Balls. Int.J.Curr.Microbiol.App.Sci. 9(10): 538-545. doi: https://doi.org/10.20546/ijcmas.2020.910.064 